\title{
A Comparison of Bancassurance and Traditional Insurer Sales Channels
}

\author{
Pang-Ru Chang, Jin-Lung Peng and Chiang Ku Fan \\ Department of Risk Management and Insurance, Shih Chien University, Taipei, Taiwan.
}

Although various sales channels exist for insurance products, no existing research compares their sales efficiency. This study offers a comparison of bancassurance and traditional sales channels in Taiwan. Using a data envelopment analysis approach, this study first computes the efficiencies of bancassurance and traditional sales channels separately. The efficiency score of the traditional sales channel is significantly higher than that of a comparable bancassurance channel. Furthermore, the efficiency relationship between the bancassurance and the traditional sales channels is independent. These findings have significant implications for the insurance industry and ongoing research in this field.

The Geneva Papers (2011) 36, 76-93. doi:10.1057/gpp.2010.34

Keywords: bancassurance; efficiency; data envelopment analysis

\section{Introduction}

By definition, bancassurance is a method for banks to distribute insurance products. However, it is also a global movement that is gradually breaking down traditional barriers among the various businesses that supply financial products and services. ${ }^{1}$ In particular, recent changes have vastly altered the organisation of the financial services industry in Europe, ${ }^{1,2}$ the United States ${ }^{3}$ and Latin America, especially with regard to the integration of banks and insurance. Banks and insurance companies engage in bancassurance activities under various strategic umbrellas, though according to the Organisation for Economic Co-operation and Development, ${ }^{4}$ banks generally pursue minority or majority holdings, full-fledged acquisitions, the creation of subsidiaries or joint ventures with holding companies. The importance of bancassurance mergers in both European and U.S. financial systems ${ }^{3}$ has prompted various bancassurance studies, focused mainly on mergers and acquisitions (M\&A) and transactions. ${ }^{5}$ In contrast, few researchers have explored the efficiency of alternative operating strategies, such as those that emerge when bancassurance products provided by a bank subsidiary come to be regarded as in-house products ${ }^{4}$ (see Figure 1).

\footnotetext{
${ }^{1}$ Benoist (2002).

${ }^{2}$ Morgan (1994).

${ }^{3}$ Fields et al. (2007).

${ }^{4}$ OECD (1992).

${ }^{5}$ For example Fields et al. (2007); Carow (2001); Boubakri et al. (2008).
} 


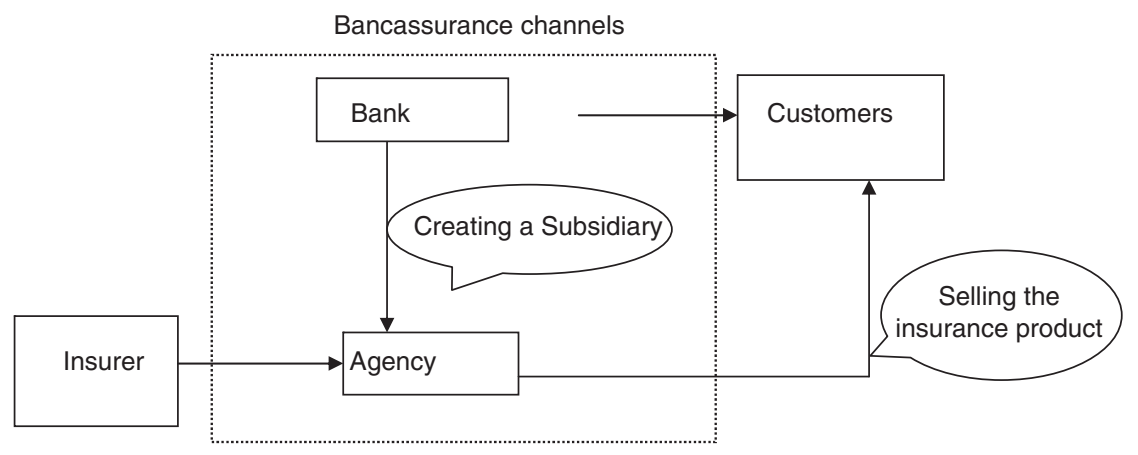

Figure 1. Bancassurance channels in Taiwan.

Furthermore, prior empirical studies mainly evaluate the efficiency of bancassurance from solely a banking perspective. For example, McKillop et al. ${ }^{6}$ investigate the cost efficiency of large Japanese banks and find that different cost function specifications lead to different results. Bergendahl ${ }^{7}$ claims that banks sell multiple products for economic reasons, such as the efficient use of fixed capacity resources, customer demand for multiple products from a single channel, and the appeal of a product combination strategy. But with their single-minded focus on banks, these studies cannot offer a comparative analysis of the efficiency of different insurance product channels from a distribution perspective.

In contrast, this study develops a unique database that includes financial data from insurance brokers and agencies in Taiwan; this data indicates the premiums and commissions earned from both traditional sales channels and bancassurance channels for each insurance company. In Taiwan's bancassurance model, an insurance agent is created as a bank subsidiary. The employees of the bank, generally referred to as financial specialists, sell the insurance products (see Figure 1). In contrast, a traditional sales channel involves only the insurer's own sales representatives. With this unique data, this study can apply data envelopment analysis (DEA) to compute the efficiencies of the separate sales channels.

Such a comparison is particularly pertinent in Taiwan, where the bancassurance model has grown increasingly important in response to the "over-banking" problem and the passage of the Financial Holding Company Law in 2001. This law allows insurance companies, banks and securities firms to affiliate with common ownership and cross-sell financial products and services, and thus to eliminate overcapacity or overlap many banks have turned to the bancassurance model. Insurance companies find that bancassurance also enables them to enter new markets rapidly and build marketing channels cost-effectively.

\footnotetext{
${ }^{6}$ McKillop et al. (1996).

${ }^{7}$ Bergendahl (1995).
} 
Although this deregulation effectively removed the restrictions on combining banking services with insurance, banks in Taiwan are still prohibited from distributing insurance products directly. Insurance companies likewise cannot offer banking services directly through their networks. However, according to the annual report of the Financial Supervisory Commission in 2007 more than 80 per cent of banks have established insurance agency companies in which they retain 100 per cent ownership to sell insurance products indirectly.

The empirical results of a comparison of the efficiency of bancassurance and traditional sales channels offer insights for life insurance companies that need to determine which sales channels to pursue. They also inform research in this area by noting the importance of considering more than one channel.

The remainder of this article is organised as follows. After a brief review of existing literature, the 'Methodology' section provides the study's methodology. The empirical's results and managerial implications appear in section 'Empirical results', followed by the conclusions of the study.

\section{Literature review}

\section{Background of efficiency measurement}

Management defines efficiency (or cost efficiency) as a characteristic of organisational outputs (e.g., effectiveness, equity, quality) and inputs (e.g., economy, cost), or the relationship between these outputs and inputs. ${ }^{8}$ In each case, efficiency involves a transformation ratio: "what has been produced or the value of what has been produced per unit of what has been consumed, or the value of what has been consumed in the process of production" (p. 670). ${ }^{9}$ Efficiency measurements have appeared in various research fields, including marketing, ${ }^{10}$ athletics, ${ }^{11}$ technology, ${ }^{12}$ information systems, ${ }^{13}$ public policy, ${ }^{14}$ banking efficiency, ${ }^{15,16}$ bancassurance and even insurance.

\section{Efficiency of bancassurance}

Many bancassurance studies focus on the benefits or enhanced value that can result from a bank-insurance company collaboration. Bergendahl ${ }^{7}$ cites several economic reasons for banks to sell multiple products, as noted previously, though Baumol et al. ${ }^{17}$ find no benefit to existing insurance companies from a consolidation with banks. However, Diamond ${ }^{18}$ proposes that because they can span short- and long-term

\footnotetext{
${ }^{8}$ Meimand et al. (2002).

${ }^{9}$ Hwang and Kao (2006).

${ }^{10} \mathrm{Wu}$ (2003), Keh et al. (2006).

11 Garcia-Sánchez (2007).

12 Jerzmanowski (2007).

${ }^{13}$ Gebauer and Schober (2006), Philip (2007).

${ }^{14}$ Vine et al. (2003), Durlauf (2005).

15 McCune (2007).

${ }^{16}$ Yao et al. (2007).

17 Baumol et al. (1982).

${ }^{18}$ Diamond (1984).
} 
liability/asset structures in the financial intermediation process, as well as attract and retain individual and corporate customers, bank-insurance company collaborations benefit both sides of the consolidation. Other studies into the effects of bank expansions into non-traditional industries mainly focus on risk reductions and value enhancements. ${ }^{19}$ For example, Saunders and Walter ${ }^{20}$ and Hughes et al. ${ }^{21}$ both show that bank consolidation reduces risk, and Felgren ${ }^{22}$ argues that banks gain cost advantages from selling insurance products, even greater than those advantages for the insurance companies themselves, because the banks already had extensive branch networks. Yet Carow ${ }^{23}$ finds that bank stock prices do not change significantly after they enter the insurance industry.

Most early research on bancassurance has tended to concur that banks gained benefits or cost advantages from the consolidation, but the findings became less consistent with regard to the insurer's benefits. That is, there is no consensus on whether bancassurance is a profitable strategy for an insurance company.

\section{The efficiency of insurers}

Studies of the efficiency of insurance companies generally evaluate the performance associated with specific insurance business activities. Many of these studies employ traditional DEA (see Figure 2). For example, De Pree and Jude ${ }^{24}$ use DEA to suggest a means for insurance companies to monitor and control their legal services and costs. Cummins et al. ${ }^{25}$ also use DEA but examine the relationships among M\&A, efficiency and economies of scale in the U.S. life insurance industry. Their results indicate that acquired firms achieved greater efficiency gains during their 1988-1995 study period than firms that had not been involved in any mergers or acquisitions. By applying DEA to measure efficiency scores and examining whether life insurers in Taiwan recognised new market structures after deregulation, $\operatorname{Lin}^{26}$ reveals that deregulation had no discernable effect on overall efficiency, pure technical efficiency or scale efficiency. Mahlberg and $\mathrm{Url}^{27}$ also analyse a panel of Austrian insurance companies from 1992 to 1999 to access the insurance industry's response to the challenges of the single market; however, their DEA-based efficiency measure seems likely to identify these companies as inefficient compared with other companies, even if they offered favourable terms to consumers. In their application of DEA, Tone and $\mathrm{Sahoo}^{28}$ examine the performance of the Life Insurance Corporation of India and find significant differences in the cost efficiency scores over the period 1994-2001. Finally,

\footnotetext{
${ }^{19}$ For example Carow (2001); Hughes et al. (1999); Mamun et al. (2005).

${ }^{20}$ Saunders and Walter (1994).

${ }^{21}$ Hughes et al. (1999).

${ }^{22}$ Felgren (1985).

${ }^{23}$ Carow (2001).

${ }^{24}$ De Pree and Jude (1995).

${ }^{25}$ Cummins et al. (1999).

${ }^{26}$ Lin (2002).

${ }^{27}$ Mahlberg and Url (2003).

28 Tone and Sahoo (2005).
} 


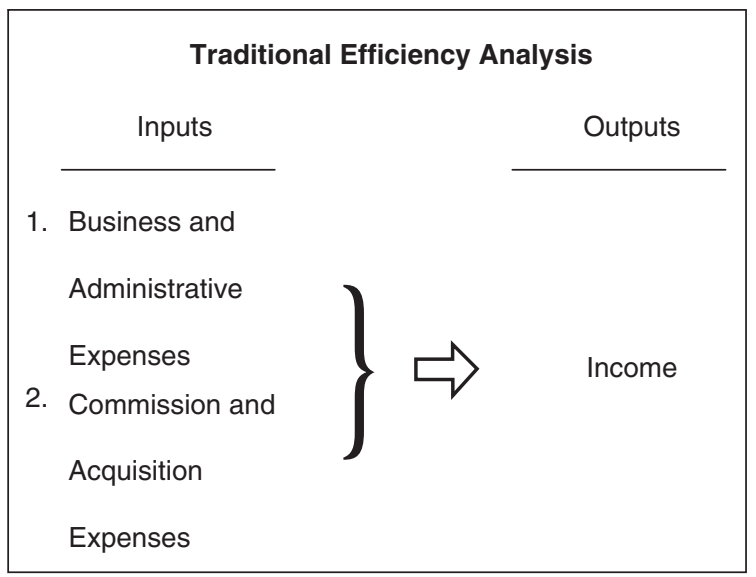

Traditional DEA

Figure 2. Traditional DEA.

Brockett et al. ${ }^{29}$ use DEA in combination with distribution-free rank-order statistics to study the relative efficiency of the different organisational structures used by U.S. property and liability insurance companies.

Furthermore, some authors alter the DEA approach slightly and use various input and output factors. Meimand et al. ${ }^{8}$ address the relative branch performance of the Accident Compensation Corporation, a New Zealand state-owned, no-fault, personal injury compensation insurance company, and use, as DEA inputs, rehabilitation, compensation costs, number of full-time cases, and number of claims managers in the branches. On the output side, they consider correct responses the first time, number of claimants managed starting each month, the number of claimants expected to have left in less than 12 months, and the number of weekly compensation payments that meet the target dates. Yao et al. ${ }^{16}$ instead use a panel data set of 22 insurance companies during the period 1999-2004 and evaluate their efficiency with DEA inputs of labour and capital and outputs of premiums, benefits and claim costs. Similarly, Jeng et al. ${ }^{30}$ examine the changes in the efficiency of U.S. life insurers before and after demutualisation, in the 1980s and 1990s, respectively. Their DEA inputs include labour, business services, equity cost, assets and underwriting, and investment expenses, whereas the outputs are benefit payments and the return on assets.

In an effort to provide more managerial insights, recent studies have adopted a modified DEA approach to efficiency evaluations. Hwang and $\mathrm{Kao}^{9}$ and $\mathrm{KaO}$ and Hwang ${ }^{31}$ take the series of relationships of two sub-processes within the overall process into account (see Figure 3). Their relational model offers reliable

${ }^{29}$ Brockett et al. (2005).

${ }^{30}$ Jeng et al. (2007).

${ }^{31}$ Kao and Hwang (2008). 
Two-Stage Efficiency Analysis

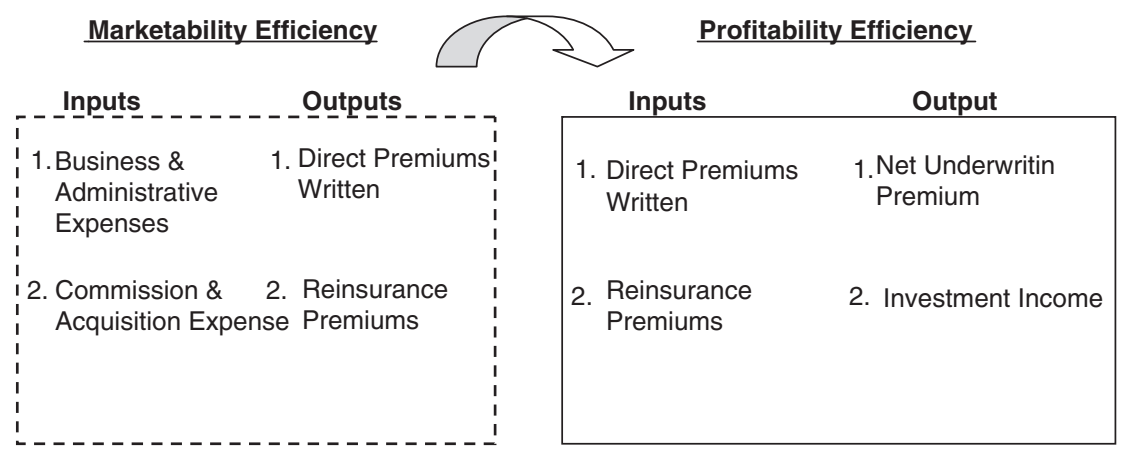

Figure 3. Two-stage DEA.

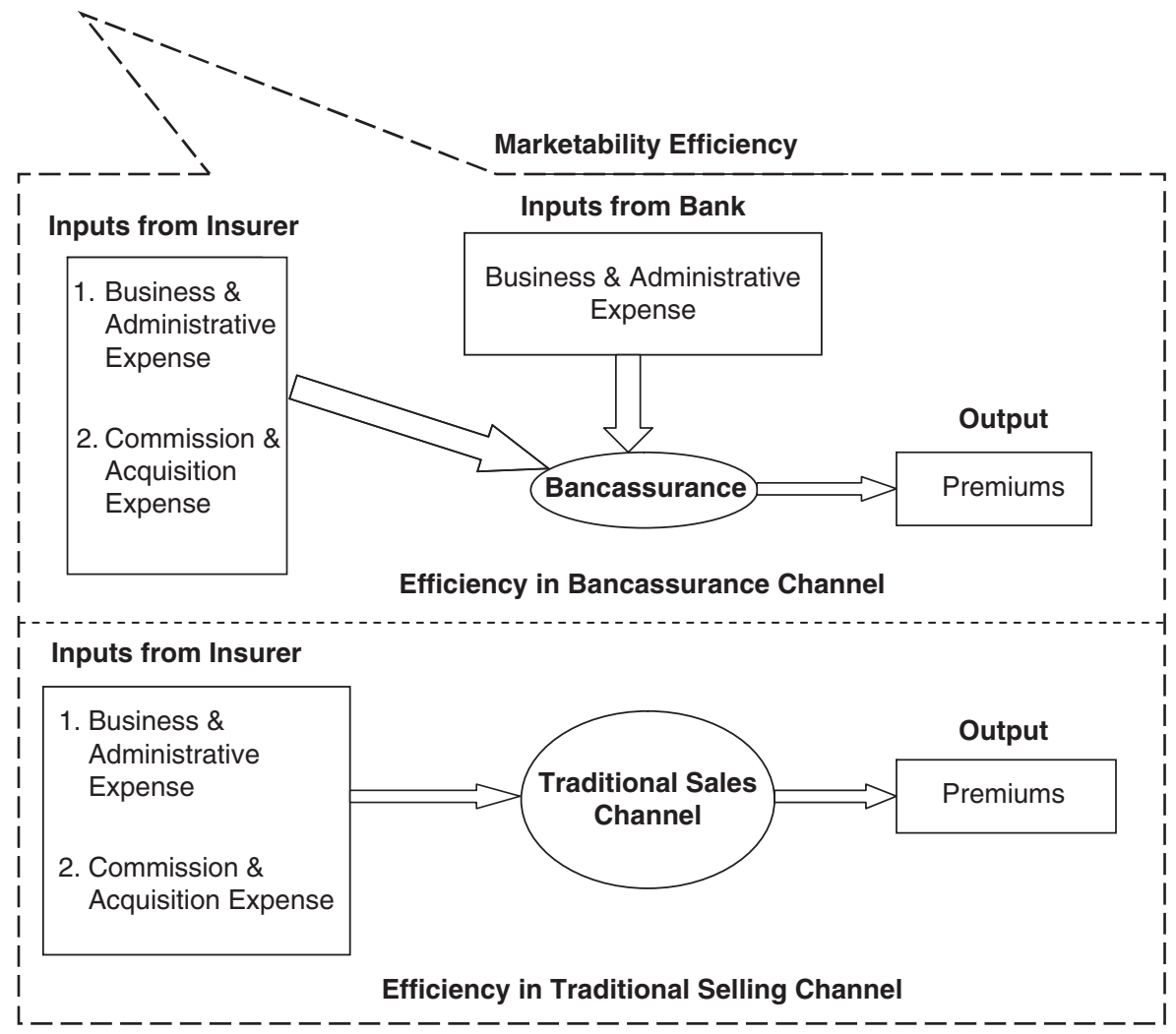

Figure 4. Efficiency comparison between traditional sales and bancassurance channels.

measures of efficiencies and can identify the causes of inefficiency accurately. In addition to the inputs in the first stage (operating expenses and insurance expenses) and the outputs of the system (underwriting profits and investment profits), 
these authors include two intermediate products in the system that represent outputs of the first stage and inputs to the second stage (i.e., direct written premiums and reinsurance premiums). Wu et $a .^{32}$ and $\mathrm{Yang}^{33}$ also employ a two-stage DEA approach to assess production and investment efficiency simultaneously in the Canadian life and health insurance industry. Their model can integrate production and investment performance, which provides managers of insurance companies with an overall performance evaluation and suggests ways to achieve efficiency systematically.

\section{Summary}

Although previous studies of bank-insurance company consolidations find that bancassurance is a profitable strategy for the bank partner, there is no consensus as to whether insurers can gain benefits or cost advantages as a result of selling their insurance products through bancassurance channels. Early studies of the efficiency of insurance, regardless of the stage of evaluation, did not address insurance marketing channels, nor did they provide a comparison of the efficiency of traditional sales vs. bancassurance marketing channels (see Figure 4).

The inputs and outputs that prior studies have used to evaluate the efficiency of insurance companies appear in Table 1. This study follows their lead to select some appropriate inputs and outputs that can assess the efficiency of traditional sales vs. bancassurance channels.

\section{Methodology}

\section{Data}

In 2006, 28 life insurance companies operated in Taiwan; the data used to evaluate their efficiency in this study comes from the 2006 Life Insurance Review of the Republic of China, published by the Taiwan Insurance Institute. Because this study explores the comparative efficiency of bancassurance and traditional sales channels, the seven life insurance companies that use only a single marketing channel are eliminated from the analysis. The data for the remaining 21 life insurance companies includes both bancassurance and traditional sales channels. Furthermore, these 21 life insurance companies are representative of the life insurance market in Taiwan, in terms of their asset rankings and market shares (see the Appendix).

\section{Procedure}

To measure the operating efficiency of the companies' decision-making units, this study applied Charnes, Cooper, and Rhoades (CRR)'s ${ }^{34}$ version of the DEA model. Similar to tests employed in prior DEA studies, ${ }^{9,31}$ the investigation then proceeded with the Mann-Whitney U, Wilcoxon and Spearman rank correlation tests to

\footnotetext{
${ }^{32} \mathrm{Wu}$ et al. (2007).

${ }^{33}$ Yang (2006).

${ }^{34}$ Charnes et al. (1978).
} 
Table 1 Inputs and outputs used to evaluate the efficiency of insurance companies

\begin{tabular}{|c|c|c|}
\hline Inputs & Outputs & References \\
\hline $\begin{array}{l}\text { 1. Rehabilitation and compensation } \\
\text { costs } \\
\text { 2. Number of full-time cases and } \\
\text { claims managers in the branch }\end{array}$ & $\begin{array}{l}\text { 1. Right first time } \\
\text { 2. Number of claimants managed starting } \\
\text { this month } \\
\text { 3. Number of claimants starting this } \\
\text { month expected to have left in less } \\
\text { than } 12 \text { months } \\
\text { 4. Number of weekly compensation } \\
\text { payments that have met the target } \\
\text { timeliness }\end{array}$ & Meimand et al. (2002) \\
\hline $\begin{array}{l}\text { 1. Business administration expenses } \\
\text { 2. Commissions } \\
\text { 3. Acquisition expenses }\end{array}$ & $\begin{array}{l}\text { 1. Direct written premiums } \\
\text { 2. Reinsurance premiums received }\end{array}$ & $\begin{array}{l}\text { Hwang and Kao } \\
(2006)\end{array}$ \\
\hline $\begin{array}{l}\text { 1. Labour } \\
\text { 2. Capital }\end{array}$ & $\begin{array}{l}\text { 1. Premium } \\
\text { 2. Benefits } \\
\text { 3. Claim costs }\end{array}$ & Yao et al. (2007) \\
\hline $\begin{array}{l}\text { 1. Labour expenses } \\
\text { 2. General operating expenses } \\
\text { 3. Capital equity } \\
\text { 4. Claims incurred }\end{array}$ & $\begin{array}{l}\text { 1. Net premiums written } \\
\text { 2. Net income }\end{array}$ & Wu et al. (2007) \\
\hline $\begin{array}{l}\text { 1. Operating expenses } \\
\text { 2. Insurance expenses } \\
\text { 3. Direct written premiums } \\
\text { 4. Reinsurance premiums }\end{array}$ & $\begin{array}{l}\text { 1. Direct written premiums } \\
\text { 2. Reinsurance premiums } \\
\text { 3. Underwriting profit } \\
\text { 4. Investment profit }\end{array}$ & $\begin{array}{l}\text { Kao and Hwang } \\
(2008)\end{array}$ \\
\hline $\begin{array}{l}\text { 1. Labour } \\
\text { 2. Business services } \\
\text { 3. Equity cost } \\
\text { 4. Assets } \\
\text { 5. Underwriting and investment } \\
\text { expenses }\end{array}$ & $\begin{array}{l}\text { 1. Benefit payments } \\
\text { 2. Return on assets }\end{array}$ & Jeng et al. (2007) \\
\hline
\end{tabular}

determine any significant differences in the inefficiency scores and ranks between traditional sales channels and bancassurance channels.

\section{Variable definitions}

Because data pertaining to the claims incurred cannot be classified by marketing channels, this variable is not appropriate for measuring efficiency. This point represents a data limitation of this study. However, as Table 2 reveals, the study includes multiple pertinent inputs. The input data for the traditional sales channels are as follows:

1. Number of sales representatives. Sales representatives are employees of an insurance company, that is, the insurance company's own sales team. 
2. Number of branches. The branches of an insurance company are distribution channels through which insurance products are available and accessible to target consumers.

3. Business and administrative expenses. These expenses include marketing and administrative costs, such as advertising, employee training fees and other expenses associated with marketing the insurance products and services.

4. Commission and acquisition expenses. These expenses include payments from insurers to sales representatives in return for their sales of insurance.

The single output variable in the traditional sales channels is the premium earned from the insurer's own sales team, including the first-year and renewed premiums.

In contrast, the inputs for bancassurance channels are as follows:

1. Agency fee and commissions. This form of payment comes from insurers and goes to agencies and their sales representatives for selling insurance.

2. Number of branches. This variable equals the total bank branches.

3. Number of financial specialists. Financial specialists are bank employees whose job is to sell financial products to the bank's customers.

4. Operating expenses. These ongoing costs in a life insurance agency context include office expenses, utilities, insurance, advertising, salaries, employee benefits, retirement benefits and so on.

The output of the bancassurance channels is the premium earned through bancassurance channels, including first-year and renewed premiums.

\section{Empirical results}

\section{Summary statistics}

The input-output data for the traditional sales and bancassurance channels appear in Tables 3 and 4, respectively. Tables 5 and 6 provide the descriptive statistics of the input-output data for these two channels. The mean and maximum number of sales representatives in the traditional channels are 8,975 and 54,579, respectively, and the mean and maximum number of financial specialists in bancassurance channels are 37,497 and 70,277. In traditional sales channels, the mean number of branches is 164 , but that number increases to 1,330 in the bancassurance channels. The mean premium

Table 2 Inputs and outputs used in two channels

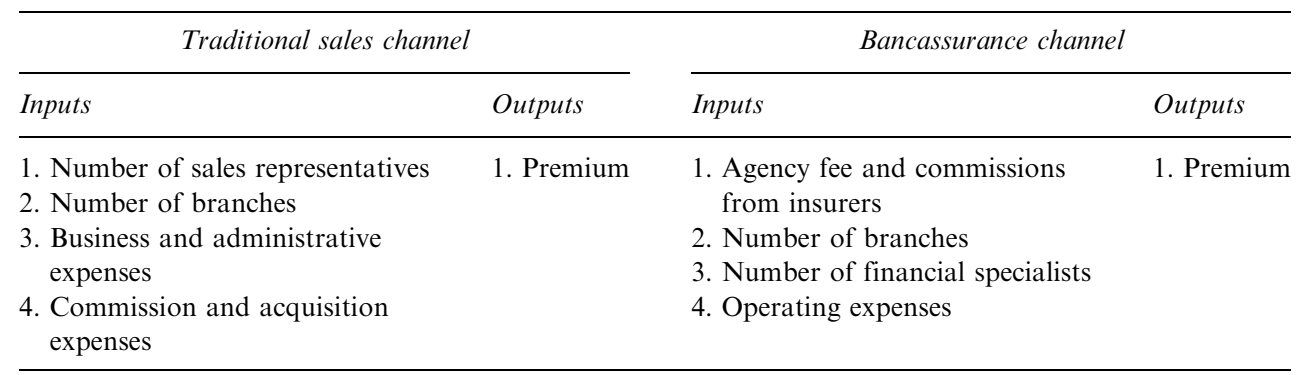


is NT\$65,739,521,000 in traditional sales channels but only $\mathbf{N T} \$ 8,461,221,000$ in bancassurance channels.

\section{DEA results}

The results, including the efficiency scores and rankings of both traditional sales and bancassurance channels determined through the DEA method, appear in Table 7.

Nine life insurance companies in Taiwan are relatively efficient in their traditional sales channels: Aegon Life, ING Life, Bank Taiwan Life, China Life, Shin Kong Life, Global Life, Sinon Life, Singfor Life and Allianz President Life. The two life insurance companies that emerge as relatively efficient in their bancassurance channels are Cathay Life and Allianz President Life. Some life insurance companies that are efficient in their traditional sales channels, such as Global Life, ING Life and Singfor Life, suffer poor performance in their bancassurance channels. In contrast, Cathay Life performs efficiently in its bancassurance channels but poorly in its traditional channels. Furthermore, six companies perform equally poorly in both channels: New

Table 3 Input and output data for life insurance companies' traditional sales channels

\begin{tabular}{|c|c|c|c|c|c|}
\hline$D M U$ & $\begin{array}{l}\text { (I) Number } \\
\text { of sales } \\
\text { representatives } \\
\text { (person) }\end{array}$ & $\begin{array}{c}\text { (I) Number } \\
\text { of } \\
\text { branches }\end{array}$ & $\begin{array}{c}\text { (I) Business } \\
\text { and } \\
\text { administrative } \\
\text { expenses } \\
(N T \$ 1,000)\end{array}$ & $\begin{array}{c}\text { (I)Commission } \\
\text { and } \\
\text { acquisition } \\
\text { expenses } \\
(N T \$ 1,000)\end{array}$ & $\begin{array}{l}\text { (O) Premium } \\
(N T \$ 1,000)\end{array}$ \\
\hline 1. Aegon Life & 663 & 30 & $1,337,867$ & $5,180,074$ & $39,376,458$ \\
\hline 2. New York Life & 1,058 & 32 & 973,365 & $1,467,436$ & $15,203,579$ \\
\hline 3. ING Life & 15,047 & 3 & $7,974,846$ & $5,867,026$ & $116,799,934$ \\
\hline $\begin{array}{l}\text { 4. Manulife Limited } \\
\text { (Taiwan Branch) }\end{array}$ & 1,554 & 31 & 498,500 & 785,053 & $4,177,513$ \\
\hline $\begin{array}{l}\text { 5. Winterthur Life } \\
\text { (Taiwan Branch) }\end{array}$ & 312 & 43 & 320,612 & 235,942 & $4,481,615$ \\
\hline 6. Bank Taiwan Life & 3,354 & 4 & 407,832 & 702,362 & $16,925,834$ \\
\hline 7. Taiwan Life & 5,536 & 63 & $1,726,253$ & $2,293,418$ & $35,100,691$ \\
\hline 8. PCA Life & 12,024 & 6 & $2,984,152$ & $4,805,150$ & $39,870,808$ \\
\hline 9. Cathay Life & 54,579 & 2,289 & $21,539,918$ & $13,920,353$ & $352,477,888$ \\
\hline 10. China Life & 3,181 & 50 & $1,077,404$ & $1,940,669$ & $52,521,993$ \\
\hline 11. Nan Shan Life & 35,360 & 387 & $9,975,193$ & $20,667,440$ & $225,750,147$ \\
\hline 12. Kuo Hua Life & 3,213 & 22 & $1,833,190$ & $2,057,888$ & $35,499,745$ \\
\hline 13. Shin Kong Life & 26,228 & 18 & $14,872,046$ & $7,601,018$ & $181,469,347$ \\
\hline 14. Fubon Life & 6,515 & 125 & $1,461,253$ & $2,911,320$ & $74,541,820$ \\
\hline 15. Global Life & 85 & 8 & 359,219 & 640,177 & $8,214,122$ \\
\hline $\begin{array}{l}\text { 16. Mass Mutual } \\
\text { Mercuries Life }\end{array}$ & 14,202 & 199 & $2,317,991$ & $6,594,178$ & $59,916,191$ \\
\hline 17. Sinon Life & 985 & 17 & 7,571 & 242,679 & $6,845,080$ \\
\hline 18. Singfor Life & 697 & 34 & 8,656 & 77,902 & $9,848,189$ \\
\hline 19. Far Glory Life & 1,811 & 34 & $1,073,777$ & $1,392,109$ & $2,7176,489$ \\
\hline 20. Hontai Life & 861 & 23 & 657,046 & $6,317,577$ & $19,895,808$ \\
\hline $\begin{array}{l}\text { 21. Allianz President } \\
\text { Life }\end{array}$ & 1,224 & 36 & 862,406 & $4,105,370$ & $54,436,693$ \\
\hline
\end{tabular}


Table 4 Input and output data for life insurance companies' bancassurance channels

\begin{tabular}{|c|c|c|c|c|c|}
\hline$D M U$ & $\begin{array}{l}\text { (I) Agency } \\
\text { fee and } \\
\text { commission } \\
\text { from insurer } \\
\text { (NT\$1000) }\end{array}$ & $\begin{array}{c}\text { (I) Number } \\
\text { of } \\
\text { branches }\end{array}$ & $\begin{array}{l}\text { (I) Number } \\
\text { of financial } \\
\text { specialists } \\
\text { (person) }\end{array}$ & $\begin{array}{c}\text { (I) Operating } \\
\text { expenses } \\
(N T \$ 1,000)\end{array}$ & $\begin{array}{l}\text { (O) Premium } \\
(N T \$ 1,000)\end{array}$ \\
\hline 1. Aegon Life & 622,411 & 2,096 & 57,007 & 179,250 & $11,018,592$ \\
\hline 2. New York Life & 479,369 & 1,576 & 42,190 & 135,771 & $6,536,526$ \\
\hline 3. ING Life & 76,322 & 1,498 & 40,022 & 92,481 & $1,550,777$ \\
\hline $\begin{array}{l}\text { 4. Manulife Limited } \\
\text { (Taiwan Branch) }\end{array}$ & 5,976 & 125 & 3,203 & 3,961 & 12,083 \\
\hline $\begin{array}{l}\text { 5. Winterthur Life } \\
\text { (Taiwan Branch) }\end{array}$ & 18,992 & 800 & 19,388 & 37,529 & 228,290 \\
\hline 6. Bank Taiwan Life & 20,610 & 557 & 15,973 & 29,963 & $1,320,042$ \\
\hline 7. Taiwan Life & 97,138 & 2,378 & 69,137 & 121,142 & $3,417,932$ \\
\hline 8. PCA Life & 19,3672 & 620 & 11,236 & 39,957 & $2,568,470$ \\
\hline 9. Cathay Life & 150,288 & 2,028 & 52,835 & 70,020 & $19,296,977$ \\
\hline 10. China Life & 724,662 & 1,732 & 45,217 & 76,792 & $17,215,492$ \\
\hline 11. Nan Shan Life & 115,846 & 1,673 & 51,226 & 105,759 & $1,822,735$ \\
\hline 12. Kuo Hua Life & 3,523 & 495 & 11,115 & 31,538 & 29,511 \\
\hline 13. Shin Kong Life & 442,960 & 2,225 & 70,277 & 135,555 & $21,200,667$ \\
\hline 14. Fubon Life & $1,099,233$ & 2,373 & 67,014 & 138,099 & $31,927,578$ \\
\hline 15. Global Life & 11,447 & 533 & 21,012 & 44,126 & 293,520 \\
\hline $\begin{array}{l}\text { 16. Mass Mutual } \\
\text { Mercuries Life }\end{array}$ & 206,571 & 1,083 & 28,370 & 39,225 & 356,6112 \\
\hline 17. Sinon Life & 82,617 & 824 & 25,680 & 57,331 & $3,377,510$ \\
\hline 18. Singfor Life & 160,350 & 868 & 29,956 & 66,148 & $1,928,318$ \\
\hline 19. Far Glory Life & 170,105 & 1,632 & 45,207 & 124,588 & $8,194,343$ \\
\hline 20. Hontai Life & 38,025 & 507 & 18,097 & 46,967 & 286,173 \\
\hline 21. Allianz President Life & $2,051,472$ & 2,327 & 63,292 & 131,528 & $41,894,000$ \\
\hline
\end{tabular}

York Life, Manulife Limited (Taiwan Branch), Nan Shan Life, Mass Mutual Mercuries Life and Hontai Life. Finally, only one life insurance company enjoys efficient performance in both traditional sales channels and bancassurance channels, namely, Allianz President Life.

As Table 7 shows, most of the efficiency scores for the traditional sales channels are higher than those for the bancassurance channels; only for Allianz President Life are the scores equal in both marketing channels. This company represents a special case, in that Allianz President Life's most promoted life insurance product through the bancassurance channel is an investment-linked policy that is very similar to its bank product. Thus, the financial specialists in banks can be easily motivated to sell these products, with which they are already familiar.

According to the Mann-Whitney $U$ and Wilcoxon tests, there is a significant difference in the efficiency scores between the traditional sales channels and the bancassurance channels (see Table 8; $U=87.00, W=318, p=0.001<0.05$ ). The efficiency mean for the traditional sales channels is greater than that for the bancassurance channels. Table 9 also shows the Spearman's rank correlation statistics, 
Table 5 Summary statistics: traditional sales channels

\begin{tabular}{|c|c|c|c|c|c|}
\hline & Observation & Mean & $\begin{array}{l}\text { Standard } \\
\text { deviation }\end{array}$ & Minimum & Maximum \\
\hline $\begin{array}{l}\text { Number of sales representatives } \\
\text { (person) }\end{array}$ & 21 & 8,975 & 13,988 & 85 & 54,579 \\
\hline Number of branches & 21 & 164 & 494 & 3 & 2,289 \\
\hline $\begin{array}{l}\text { Business and administrative } \\
\text { expenses (NT } \$ 1,000)\end{array}$ & 21 & $3,441,385$ & $5,608,787$ & 7,571 & $21,539,918$ \\
\hline $\begin{array}{l}\text { Commission and acquisition } \\
\text { expenses (NT\$1,000) }\end{array}$ & 21 & $4,276,435$ & $5,033,441$ & 77,902 & $20,667,440$ \\
\hline Premium (NT\$1,000) & 21 & $65,739,521$ & $87,585,236$ & $4,177,513$ & 888 \\
\hline
\end{tabular}

Table 6 Summary statistics: bancassurance channels

\begin{tabular}{|c|c|c|c|c|c|}
\hline & Observation & Mean & Standard deviation & Minimum & Maximum \\
\hline $\begin{array}{l}\text { Agency fee and commissions } \\
\text { from insurers (NT\$1,000) }\end{array}$ & 21 & 322,457 & 488,219 & 3,523 & $2,051,472$ \\
\hline $\begin{array}{l}\text { Number of financial } \\
\text { specialists (person) }\end{array}$ & 21 & 37,497 & 21,029 & 3,203 & 70,277 \\
\hline Number of branches & 21 & 1,330 & 737 & 125 & 2,378 \\
\hline $\begin{array}{l}\text { Operating expenses } \\
(\mathrm{NT} \$ 1,000)\end{array}$ & 21 & 81,320 & 47,665 & 3,961 & 179,250 \\
\hline Premium (NT\$1,000) & 21 & $8,461,221$ & $11,563,630$ & 12,083 & $41,894,000$ \\
\hline
\end{tabular}

which reveal no efficiency rank relationship across the 21 companies for bancassurance vs. traditional sales channels $(p=0.170>0.05)$.

The comparison of the efficiency scores (Figure 5) and efficiency ranks (Figure 6) indicates that the efficiency of the traditional sales channels is higher on average than that of the bancassurance channels. However, the efficiency rank of the traditional sales channels exhibits no relationship with that of the bancassurance channels. That is, there is no efficiency rank relationship between traditional sales and bancassurance channels in Taiwan.

\section{Managerial implications}

Some interesting findings emerge from these empirical results. In Taiwan's life insurance industry, both Cathay Life and Fubon Life operate under different financial holding companies and also have banks that operate under their financial holding company and sell insurance exclusively (see Figure 7). Therefore, their efficiency scores through the bancassurance channels reach high levels (Cathay Life=1, Fubon Life $=0.9889)$. However, their efficiency scores for their traditional sales channels are only 0.429 (Cathay Life) and 0.836 (Fubon Life).

The DEA results reveal that the efficiency of the two distribution channels is heterogeneous, for four discernable reasons. First, in traditional sales channels, the life insurance sales representatives concentrate on selling the products of one insurance 
Table 7 Efficiency of bancassurance and traditional sales channels

\begin{tabular}{|c|c|c|c|c|}
\hline \multirow[t]{2}{*}{$D M U$} & \multicolumn{2}{|c|}{ Traditional sales channels } & \multicolumn{2}{|c|}{ Bancassurance channels } \\
\hline & Score & Rank & Score & Rank \\
\hline 1. Aegon Life & 1 & 1 & 0.4433 & 9 \\
\hline 2. New York Life & 0.5525 & 16 & 0.3475 & 11 \\
\hline 3. ING Life & 1 & 1 & 0.1582 & 16 \\
\hline 4. Manulife Limited (Taiwan Branch) & 0.1745 & 21 & 0.0015 & 21 \\
\hline 5. Winterthur Life (Taiwan Branch) & 0.6745 & 14 & 0.0093 & 18 \\
\hline 6. Bank Taiwan Life & 1 & 1 & 0.4987 & 7 \\
\hline 7. Taiwan Life & 0.5453 & 17 & 0.2740 & 13 \\
\hline 8. PCA Life & 0.6922 & 13 & 0.4485 & 8 \\
\hline 9. Cathay Life & 0.4291 & 19 & 1 & 1 \\
\hline 10. China Life & 1 & 1 & 0.7652 & 5 \\
\hline 11. Nan Shan Life & 0.4711 & 18 & 0.1225 & 17 \\
\hline 12. Kuo Hua Life & 0.8665 & 10 & 0.0065 & 19 \\
\hline 13. Shin Kong Life & 1 & 1 & 0.8798 & 4 \\
\hline 14. Fubon Life & 0.8364 & 11 & 0.9888 & 3 \\
\hline 15. Global Life & 1 & 1 & 0.1996 & 15 \\
\hline 16. Mass Mutual Mercuries Life & 0.3831 & 20 & 0.3183 & 12 \\
\hline 17. Sinon Life & 1 & 1 & 0.4186 & 10 \\
\hline 18. Singfor Life & 1 & 1 & 0.2080 & 14 \\
\hline 19. Far Glory Life & 0.8130 & 12 & 0.5106 & 6 \\
\hline 20. Hontai Life & 0.5624 & 15 & 0.0059 & 20 \\
\hline 21. Allianz President Life & 1 & 1 & 1 & 1 \\
\hline
\end{tabular}

Table 8 Mann-Whitney $\mathrm{U}$ and Wilcoxon W tests of efficiency comparison of traditional sales and bancassurance channels

\begin{tabular}{lcccc}
\hline Efficiency score & Mean & $\begin{array}{c}\text { Standard } \\
\text { deviation }\end{array}$ & $\begin{array}{c}\text { Mann-Whitney } U \\
(p \text {-value })\end{array}$ & $\begin{array}{c}\text { Wilcoxon W } \\
(p \text {-value })\end{array}$ \\
\hline Traditional sales channel & 0.7620 & 0.2603 & 87.000 & 318.000 \\
Bancassurance channel & 0.4198 & 0.3283 & $(0.001)$ & $(0.001)$ \\
\hline
\end{tabular}

Table 9 Spearman's rank correlation coefficients of efficiency in traditional sales and bancassurance channels

Traditional sales channel-bancassurance channel

company, which explains why the efficiency scores of these channels tend to be higher than those of the bancassurance channels. In contrast, financial specialists in a bank setting must push various financial products, in addition to selling insurance products. Second, the financial specialists offer customers several choices among products provided by many different insurance companies. In turn, they can offer 


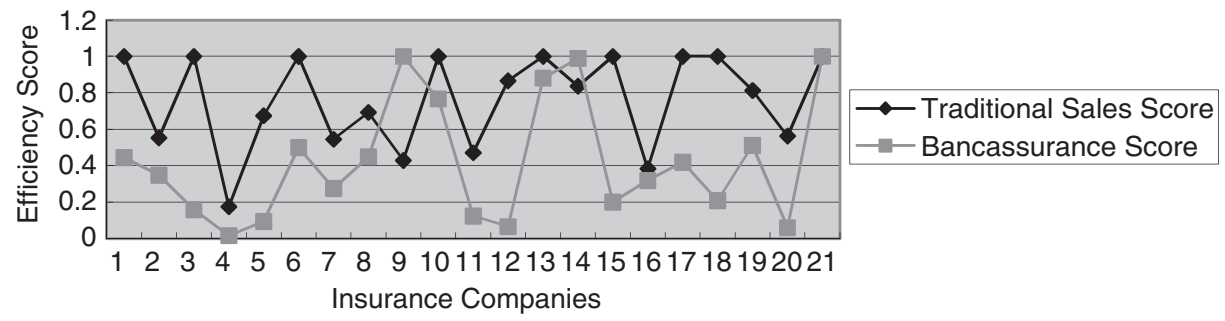

Figure 5. Efficiency scores comparison for each insurance company between traditional sales and bancassurance channels.

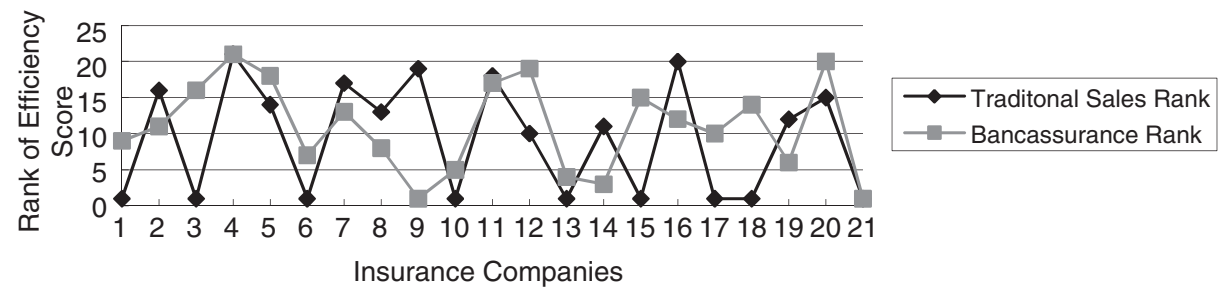

Figure 6. Efficiency ranks comparison for each insurance company between traditional sales and bancassurance channels.
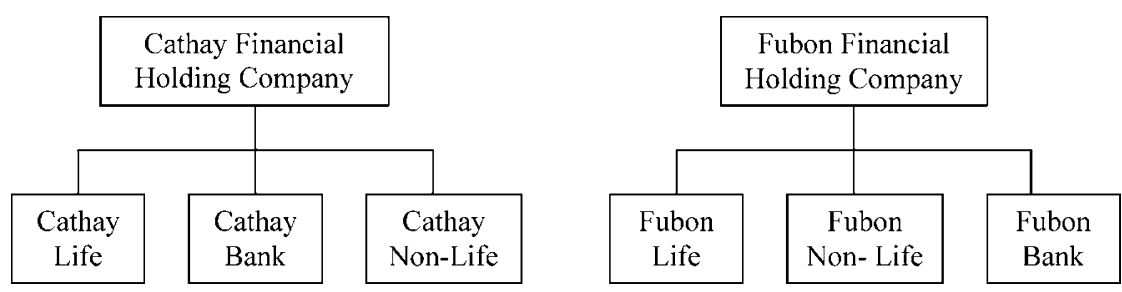

Figure 7. Organisational forms of Cathay financial holding company and Fubon financial holding company.

better-informed advice to customers and thereby reduce customers' search costs. ${ }^{35}$ This ability, though beneficial for customers, lowers the efficiency score for the bancassurance channels. Third, banks benefit from the strength of their distribution channels, whereas insurance companies need to generate more commissions through bancassurance activities to gain additional business. This scenario further increases the inefficiency in the bancassurance channels. Fourth, some insurance companies (e.g., Manulife Limited, Nan Shan Life, Hontai Life) just began engaging in bancassurance activities as of 2006. Their lack of experience with bancassurance likely explains their inefficient scores.

\footnotetext{
${ }^{35}$ Trigo-Gamarra (2008).
} 
Despite this inefficiency, insurance companies prefer to sell their products through banks, because it offers a cost-effective means to enter the insurance market rapidly and build marketing channels. The fixed costs and scale economics associated with running and managing traditional sales channels suggest that smaller firms have a comparative disadvantage in this context. ${ }^{36}$ Moreover, because banks' branches are located all over the geographic market, they can attract large numbers of customers more easily than can insurance companies. Finally, bank products and insurance products are complementary, so the bancassurance channel can satisfy customers' preferences for one-stop shopping. Therefore, even with the inefficiency of the bancassurance channels, insurance companies will likely continue to sell their products through banks; to improve their performance in these channels, life insurance companies in Taiwan must choose appropriate bank partners.

Two recent phenomena also suggest that the efficiency differences between traditional sales channels and bancassurance channels will decrease. First, salespeople in traditional sales channels are starting to sell more diversified financial products. Second, insurance companies are providing more training to the financial specialists in banks regarding insurance products, which should improve the premiums earned through bancassurance channels.

However, these two channels appear likely to continue to coexist in the life insurance market in Taiwan, similar to those of the United States ${ }^{37}$ and Germany, ${ }^{35}$ where independent agents and exclusive agents continue to persist in the long run. ${ }^{38}$ Bancassurance and traditional sales channels can coexist because they offer different services.

Therefore, this study suggests that insurers should engage in bancassurance activities, especially if they can do so through M\&A and engage in an exclusive relationship with a bank to sell their insurance products specifically. As stated previously, more than 80 per cent of Taiwanese banks have established insurance agencies or brokerages, but according to the findings in Table 7, only those agencies that sell insurance through banks owned by the same financial holding company achieve good efficiency scores.

\section{Conclusion}

This study has applied a CCR version of the DEA model to measure the efficiency scores of traditional sales channels and bancassurance channels. It also features MannWhitney U, Wilcoxon and Spearman rank correlation tests that determine whether significant differences mark the efficiency scores and ranks of the two channels. The results indicate that the average efficiency scores of traditional sales channels are significantly higher than those of bancassurance channels. Companies such as ING Life, Global Life and Singfor Life must work to improve their bancassurance efficiency, perhaps by changing the banks with which they have established partnerships.

The relationship between bancassurance channels and traditional sales channels is independent with regard to their efficiency. That is, life insurance companies that

\footnotetext{
${ }^{36}$ Kim et al. (1996).

${ }^{37}$ Berger et al. (1997).

${ }^{38}$ Seog (1999).
} 
perform well in their traditional sales channels do not necessarily perform well in their bancassurance channels.

Finally, the results suggest that a salesperson in a traditional sales channel sells diversified financial products, but financial specialists in banks need more training about insurance products to function well in bancassurance channels. In addition, insurers should undertake their bancassurance activities by pursuing M\&A, which can help minimise the difference in the efficiency of the bancassurance channel vs. the traditional sales channel.

\section{Acknowledgement}

The authors gratefully acknowledge the helpful comments of the editor, referees and Larry Tzeng, Chenghsien Tsai and the CARDIF Bancassurance Research Center at Shih-Chien University for financial support.

\section{References}

Baumol, W.J., Panzar, J.C. and Willig, R.D. (1982) Contestable Markets and the Theory of Industry Structure, New York: Harcourt College Pub.

Benoist, G. (2002) 'Bancassurance: The new challenges', The Geneva Papers on Risk and Insurance 27(3): 295-303.

Bergendahl, G. (1995) 'The profitability of Bancassurance for European banks', International Journal of Bank Marketing 13(1): 17-29.

Berger, A.N., Cummins, J.D. and Weiss, M.A. (1997) 'The coexistence of multiple distribution systems for financial services: The case of property-liability insurance', Journal of Business 70: 515-546.

Boubakri, N., Dionne, G. and Triki, T. (2008) 'Consolidation and value creation in the insurance industry: The role of governance', Journal of Banking and Finance 32(1): 56-68.

Brockett, P.L., Cooper, W.W., Golden, L.L., Rousseau, J.J. and Wang, Y. (2005) 'Financial intermediary versus production approach to efficiency of marketing distribution systems and organizational structure of insurance companies', The Journal of Risk and Insurance 72(3): 393-412.

Carow, K.A. (2001) 'The wealth effects of allowing bank entry into the insurance industry', The Journal of Risk and Insurance 68(1): 129-150.

Charnes, A., Cooper, W.W. and Rhodes, E. (1978) 'Measuring the efficiency of decision making units', European Journal of Operational Research 2(6): 429-444.

Cummins, D., Tennyson, S. and Weiss, M.A. (1999) 'Consolidation and efficiency in the US life insurance industry', Journal of Banking and Finance 23: 325-357.

De Pree Jr., C.M. and Jude, R.K. (1995) 'A tool to help insurance company management assess attorney efficiency and productivity', CPCU Journal 48(3): 155-162.

Diamond, D.W. (1984) 'Financial intermediation and delegated monitoring', Review of Economic Studies 51: 393-414.

Durlauf, S.N. (2005) 'Racial profiling as a public policy questions: Efficiency, equity, and ambiguity', American Economic Review 95(2): 132-136.

Felgren, S. (1985) 'Banks as insurance agencies: Local constraints and competitive advances', New England Economic Review 5(September/October): 34-39.

Fields, L.P., Froser, D.R. and Kolari, J.W. (2007) 'Bidder returns in Bancassurance mergers: Is there evidence of synergy?' Journal of Banking and Finance 31: 3646-3662.

Garcia-Sánchez, I.M. (2007) 'Efficiency and effectiveness of Spanish football teams: A three-stage-DEA approach', Central European Journal of Operations Research 15(1): 21-45.

Gebauer, J. and Schober, F. (2006) 'Information system flexibility and the cost efficiency of business process', Journal of the Association for Information Systems 7(3): 122-146.

Hughes, J.P., Lang, W.W., Mester, L.J. and Moon, C-G. (1999) 'The dollars and sense of bank consolidation', Journal of Banking and Finance 23(2-3): 291-324. 
Hwang, S.N. and Kao, T.L. (2006) 'Measuring managerial efficiency in non-life insurance companies: An application of the two-stage data envelopment analysis technique', International Journal of Management 23: 699-720.

Jeng, V., Lai, G.C. and McNamara, M.J. (2007) 'Efficiency and demutualization: Evidence from the U.S. life insurance industry in the 1980s and 1990s', The Journal of Risk and Insurance 74(3): 683-711.

Jerzmanowski, M. (2007) 'Total factor productivity differences: Appropriate technology vs. efficiency', European Economic Review 51(8): 2080-2110.

Kao, C. and Hwang, S.N. (2008) 'Efficiency decomposition in two-stage data envelopment analysis: An application to non-life insurance companies in Taiwan', European Journal of Operational Research 185: 418-429.

Keh, H.T., Chu, S. and Xu, J. (2006) 'Efficiency effectiveness and productivity of marketing in services', European Journal of Operational Research 170: 265-276.

Kim, W., Mayers, D. and Smith Jr., C.W. (1996) 'On the choice of insurance distribution systems', Journal of Risk and Insurance 63: 207-227.

Lin, L.F. (2002) Deregulation and Efficiency in the Taiwan Life Insurance Industry, Temple University, PhD dissertation.

Mahlberg, B. and Url, T. (2003) 'Effects of the single market on the Austrian insurance industry', Empirical Economics 28(4): 813-838.

Mamun, A., Hassan, M.K. and Maroney, N. (2005) 'The wealth and risk effects of the Gramm-LeachBliley Act (GLBA) on the US banking industry', Journal of Business Finance and Accounting 32(1-2): 351-388.

McCune, J. (2007) 'Efficiency has been flat: Where is it headed?' ABA Banking Journal 99(5): 14.

McKillop, D.G., Glass, J.C. and Morikawa, Y. (1996) 'The composite cost function and efficiency in giant Japanese banks', Journal of Banking and Finance 20(10): 1651-1671.

Meimand, M., Cavana, R.Y. and Laking, R. (2002) 'Using DEA and survival analysis for measuring performance of branches in New Zealand's accident compensation corporation', Journal of the Operational Research Society 53: 303-313.

Morgan, G. (1994) 'Problems of integration and differentiation in the management of 'Bancassurance', The Service Industries Journal 14(2): 153-169.

OECD (1992) Insurance and other Financial Service: Structural Trends, Paris: The Organization for Economic Cooperation and Development.

Philip, G. (2007) 'IS strategic planning for operational efficiency', Information Systems Management 24(3): $247-264$

Saunders, A. and Walter, I. (1994) Universal Banking in the United States: What Could We Gain? What Could We Lose? Oxford: Oxford University Press.

Seog, S.H. (1999) 'The coexistence of distribution systems when consumers are not informed', Geneva Papers on Risk and Insurance Theory 24(2): 173-192.

Tone, K. and Sahoo, B.K. (2005) 'Evaluating cost efficiency and returns to scale in the life insurance corporation of India using data envelopment analysis', Socio-Economic Planning Sciences 39(4): 261-285.

Trigo-Gamarra, L. (2008) 'Reasons for the coexistence of different distribution channels: An empirical test for the German insurance market', The Geneva Papers on Risk and Insurance-Issues and Practice 33: 389-407.

Vine, E., Hamrin, J., Eyre, N., Crossley, D., Maloney, M. and Watt, G. (2003) 'Public policy analysis of energy efficiency and load management in changing electricity businesses', Energy Policy 31(5): 405-431.

Wu, D., Yang, Z., Vela, S. and Liang, L. (2007) 'Simultaneous analysis of production and investment performance of Canadian life and health insurance companies using data envelopment analysis', Computers \& Operations Research 34(1): 180-198.

Wu, Z. (2003) 'Market efficiency in the reformed Chinese grain marketing system', China Economic Review 14(2): 115-131.

Yang, Z. (2006) 'A two-stage DEA model to evaluate the overall performance of Canadian life and health insurance companies', Mathematical and Computer Modeling 43: 910-919.

Yao, S., Jiang, C., Feng, C. and Willenbockel, D. (2007) 'WTO challenges and efficiency of Chinese banks', Applied Economics 39(5): 629-643. 


\begin{abstract}
About the Authors
Pang-Ru Chang is Assistant Professor in the Department of Risk Management and Insurance of the Shih-Chien University. Her research focuses on bancassurance and corporate governance. She has published articles in the Journal of Innovation and Management.

Jin-Lung Peng is Associate Professor in the Department of Risk Management and Insurance and Director of Cardif Bancassurance Research Center of Shih-Chien University. His research focuses on bancassurance and financial holding company. $\mathrm{He}$ has published in journals including Journal of Insurance Issue, The Geneva Papers on Risk and Insurance - Issues and Practice, and elsewhere.

Chiang Ku Fan is Associate Professor in the Department of Risk Management and Insurance at Shih-Chien University. His research focuses on bancassurance, insurance and bank service, MCDM, efficiency analysis, human resources management in insurance industry. He has published over 20 journal articles in the Journal of Grey System, The Service Industry Journal, Direct Marketing: An International Journal, Journal of Testing and Evaluation, Journal of Information and Optimization Sciences and International Journal of Training Development.
\end{abstract}

\title{
Appendix
}

See Table A1.

Table A1 Asset ranks and market shares of the sample in 2006

\begin{tabular}{rlrc}
\hline$D M U$ & Company & Rank by assets & Market share (\%) \\
\hline 1 & Aegon Life & 13 & 2.75 \\
2 & New York Life & 15 & 1.06 \\
3 & ING Life & 4 & 8.15 \\
4 & Manulife Limited (Taiwan Branch) & 25 & 0.29 \\
5 & Winterthur Life (Taiwan Branch) & 23 & 0.31 \\
6 & Bank Taiwan Life & 14 & 1.18 \\
7 & Taiwan Life & 7 & 2.45 \\
8 & PCA Life & 11 & 2.78 \\
9 & Cathay Life & 1 & 24.58 \\
10 & China Life & 5 & 3.66 \\
11 & Nan Shan Life & 2 & 15.74 \\
12 & Kuo Hua Life & 6 & 2.48 \\
13 & Shin Kong Life & 3 & 12.66 \\
14 & Fubon Life & 9 & 5.20 \\
15 & Global Life & 19 & 0.57 \\
16 & Mass Mutual Mercuries Life & 8 & 4.18 \\
17 & Sinon Life & 22 & 0.48 \\
18 & Singfor Life & 16 & 0.69 \\
19 & Far Glory Life & 12 & 1.90 \\
20 & Hontai Life & 17 & 1.39 \\
21 & Allianz President Life & 10 & 3.80 \\
\hline
\end{tabular}

